\title{
PENGARUH BUDAYA TERHADAP PANGAN,SISTEM BUDAYA TERHADAP MAKANAN,MASALAH BUDAYAKAN DAN MAKANAN TERHADAP GIZI,SERTA SOLUSI MENGATASI MASALAH BUDAYA DAN MAKAN TERHADAP GIZI DAN KESEHATAN
}

\author{
Riskawati \\ Universitas Islam Negri Alauddin Makassar \\ Bontolenivmpangang Desa Julumate, ne \\ Kec Pol-SeUl Kab Gowa \\ Email : riskawati042021@gmail.com
}

\section{Pengaruh budaya terhadap pangan}

Keadaan ini muncul karena adanya anggapan makanan utama merupakan makanan terpenting jika dibanding dengan jenis makanan lainnya. Suatu hidangan dianggap tidak akan sempurna jika tidak terdapat makanan pokok di dalamnya. Meskipun begitu, pandangan sosial budaya menganggap makanan mempunyai arti yang lebih luas daripada hanya sebagai sumber gizi. Hal ini terkait dengan adanya kepercayaan, posisi, prestis, pertemanan serta kedamaian dalam kehidupan manusia.

$57 \%$ kepala rumah tangga berpendidikan dasar, dan $57,9 \%$ bekerja sebagai petani pemilik. $81,3 \%$ ibu rumah tangga berpendidikan dasar, 66,4\% bekerja sebagai petani pemilik, dan 75,7\% ibu berpengetahuan gizi kurang. 38,3\% rumah tangga dengan jumlah anggota keluarga antara 5-6 orang. dan $70,1 \%$ rumah tangga miskin. $51,4 \%$ rumah tangga menyukai satu jenis makanan pokok, $83,2 \%$ rumah tangga menggunakan ubi jalar sebagai simbol nilai komunikasi, dan $67,3 \%$ rumah tangga menganggap ubi jalar sebagai simbol nilai religi. 51,4\% rumah tangga menggunakan lebih dari satu jenis makanan pokok sebagai simbol nilai persahabatan, $75 \%$ rumah tangga memilih ubi jalar sebagai simbol nilai ekonomi, dan 78,5\% rumah tangga menggunakan ubi jalar dalam tradisi. Hasil penelitian ini menunjukkan semakin tinggi strata sosial semakin bervariasi makanan pokok yang dikonsumsi. Sebaliknya semakin kuat faktor budaya yang dianut, semakin sedikit jenis makanan pokok yang dikonsumsi.

\section{SISTEM BUDAYA TERHADAP MAKANAN}

Dari sekian banyak unsur-unsur yang hidup dalam masayarakat, salah satu kebutuhan yang harus terpenuhi untuk melangsungkan kehidupan adalah makan dan minum. Makanan merupakan wujud dari kebudayaan manusia oleh karena dalam proses pengolahan bahan-bahan mentah sehingga menjadi makanan, begitu pula dalam perwujudannya, cara penyajiannya dan pengkonsumsiannya sampai menjadi tradisi, hanya mungkin terjadi karena adanya dukungan dan adanya hubungan 
kait-mengkait dengan berbagai aspek yang ada dalam kehidupan sosial dan dengan berbagai unsur kebudayaan yang ada dalam masyarakat tersebut

\section{MASALAH BUDAYA DAN MAKANAN TERHADAP GIZI}

Pola asuh gizi yang juga merupakan pola perilaku adalah praktek pemberi perawatan yang dilakukan baik oleh orang tua, nenek, pengasuh, tenaga perawat atau bahkan tetangga dan saudara balita yang berkaitan dengan status gizi. Ada tiga faktor yang mempengaruhi pola asuh gizi, yaitu sosiobudaya, keadaan politik dan keadaan ekonomi. Pada penelitian ini, dari ketiga faktor tersebut faktor politik dianggap mempunyai keadaan atau gambaran yang sama dengan daerah-daerah di wilayah Propinsi Jawa Tengah pada umumnya dan Kabupaten Demak khususnya. Faktor ekonomi sudah tergambarkan pada saat penentuan lokasi penelitian, dimana daerah Pecuk mempunyai keadaan ekonomi yang tidak mendukung timbulnya status gizi yang baik, sehingga faktor keadaan sosiobudaya setempat yang belum didapat gambaran serta kaitannya dengan pola asuh gizi yang dapat mempengaruhi status gizi balita di daerah tersebut, yang kemudian di fokuskan pada penelitian ini adalah pada sistem budayanya.

Gizi adalah suatu proses organisme menggunakan makanan yang dikonsumsi secara normal melalui proses digesti, absobsi, transportasi, penyimpanan, metabolisme dan pengeluaran zat-zat yang tidak digunakan untuk mempertahankan kehidupan, pertumbuhan dan fungsi normal dari organ-organ, serta menghasilkan energi.

Gizi dalam kesehatan masyarakat

Terkait erat dengan "gisi kesehatan masyarakat" adalah "kesehatan gizi masyarakat," yang mengacu pada cabang populasi terfokus kesehatan masyarakat yang memantau diet, status gizi dan kesehatan, dan program pangan dan gizi, dan memberikan peran kepemimpinan dalam menerapkan publik kesehatan prinsip-prinsip untuk kegiatan yang mengarah pada

Definisi Status Gizi

Status gizi adalah ekspresi dari keadaan keseimbangan dalam bentuk variabel tertentu atau dapat dikatakan bahwa status gizi merupakan indikator baik-buruknya penyediaan makanan sehari-hari. Adapun definisi lain menurut Suyatno, Ir. Mkes, Status gizi yaitu Keadaan yang diakibatkan oleh status keseimbangan antara jumlah asupan ("intake") zat gizi dan jumlah yang dibutuhkan ("requirement") oleh tubuh untuk berbagai fungsi biologis: (pertumbuhan fisik, perkembangan, aktivitas, pemeliharaan kesehatan, dan lainnya). Status gizi yang baik diperlukan untuk mempertahankan derajat kebugaran dan kesehatan, membantu pertumbuhan bagi anak, serta menunjang pembinaan prestasi olahragawan.

\section{Cara-cara Perbaikan Status Gizi}

Pengaturan makanan adalah upaya untuk meningkatkan status gizi,

antara lain menambah berat badan dan meningkatkan kadar $\mathrm{Hb}$. Berikut adalah pengaturan makanan yang bertujuan untuk meningkatkan status gizi: Kebutuhan energi dan zat gizi ditentukan menurut umur, berat badan, jenis kelamin, dan aktivitas

Susunan menu seimbang yang berasal dari beraneka ragam bahan makanan, vitamin, dan mineral sesuai dengan kebutuhan 
Menu disesuaikan dengan pola makan;

Peningkatan kadar $\mathrm{Hb}$ dilakukan dengan pemberian makanan sumber zat besi yang berasal dari bahan makanan hewani karena lebih banyak diserap oleh tubuh daripada sumber makanan nabati;

Selain meningkatkan konsumsi makanan kaya zat besi, juga perlu menambah makanan yang banyak mengandung vitamin C, seperti pepaya, jeruk, nanas, pisang hijau, sawo kecik, sukun, dll.Penanggulangan Masalah GiziSeperti yang telah kita ketahui, masalah gizi yang salah kian marak di negara kita. Dengan demikian diperlukan penanggulangan guna memperbaiki gizi masyarakat Indonesia. Berikut ini cara-cara yang dapat dilakukan untuk menanggulangi gizi salah, baik gizi kurang maupun gizi lebih.

1) Penanggulangan masalah gizi kurang

a. Upaya pemenuhan persediaan pangan nasional terutama melalui peningkatan produksi beraneka ragam pangan;

b. Peningkatan usaha perbaikan gizi keluarga (UPGK) yng diarahkan pada pemberdayaan keluarga untuk meningkatkan ketahanan pangan tingkat rumah tangga;

c. Peningkatan upaya pelayanan gizi terpadu dan sistem rujukan dimulai dari tingkat Pos Pelayanan Terpadu (Posyandu), hingga Puskesmas dan Rumah Sakit;

d. Peningkatan upaya keamanan pangan dan gizi melalui Sistem Kewaspadaan Pangan dan Gizi (SKPG);

e. Peningkatan komunikasi, informasi, dan edukasi di bidang pangan dan gizi masyaraka

\section{Daftar pustaka}

PENGARUH EDUKASI GIZI TERHADAP PENGETAHUAN DAN SIKAP ANAK SEKOLAH DASAR DALAM PEMILIHAN JAJANAN SEHAT: LITERATURE REVIEW The

LITERATURE REVIEW: FAKTOR-FAKTOR YANG BERHUBUNGAN DENGAN STATUS GIZI BALITA

Pengentasan Rumah Tangga Rawan Pangan dan Gizi: Besaran, Penyebab, Dampak, dan Kebijakan Dimensi etis terhadap budaya makan dan dampaknya pada masyarakat 
